DOI: 10.20472/IAC.2018.935.029

DAVID MEREDITH

Webster University Thailand, Thailand

\title{
A CAUSAL RELATIONSHIP MODEL OF UNDERGRADUATE STUDENTS' WILLINGNESS TO COMMUNICATE ENGLISH
}

\begin{abstract}
:
The purpose of this research is to explore the critical factors that affect undergraduate students' Willingness to Communicate in English (WTC). The data was collected from a sample of 416 respondents using a questionnaire to measure attitudes. Data was analysed using SPSS and Mplus 6.12 computer programmes. The findings revealed that students' Perceived Communication Apprehension (PCA) could influence WTC indirectly via Attitude Toward Willingness to Communicate (AWTC) and Perceived Behavioural Control (PBC), whilst WTC was not affected from PCA indirectly via the Subjective Norm (SN). Students were found to be tense and nervous about speaking English with their friends, strangers, and new acquaintance which was associated with a lack of confidence. However, if activities were perceived to be fun students were more willing to communicate. This research is useful for teachers of English as it can increase awareness of the causes and effects of anxiety on students' learning and suggest teaching methodologies that might reduce nervousness and encourage students' willingness to communicate: thereby helping to improve their English oral communication skills.
\end{abstract}

\section{Keywords:}

Willingness to Communicate English, Perceived Communication Apprehension, Attitude Toward Willingness to Communicate, Subjective Norms, Perceived Behavioural Control

JEL Classification: 121 


\section{Introduction}

In an increasingly globalized and competitive world, the ability to be able to communicate in the English language can provide a significant competitive advantage for a young learner when seeking employment. Several Thai universities have opened international programmes using English as the medium of instruction. Such programmes are popular with students as companies, especially those that are globally based, prefer to recruit students who can speak fluent English. From a business perspective, a company with a significant number of employees, able to communicate in English, has greater potential to grow and expand internationally.

Yet, in Thailand, learning English presents a major challenge for many students. At university level some students are able to master the language, but for the vast majority success eludes them and standards remain stubbornly low. In fact, the English Proficiency Index (EPI) places Thailand $55^{\text {th }}$ out of 60 countries with only Kazakhstan below Thailand in the Asia region (EF, 2012).

The Willingness to Communicate (WTC) in a second or foreign language represents a psychological preparedness for using that language (Maclntyre, 2007). Such preparedness is an important concept in language acquisition and communication theory. Maclntyre and Charos (1996) argue that the primary reason for learning a language is to be able to communicate and that such communication is an indispensable part of language acquisition: whether it is for meeting new people, travelling, experiencing other cultures, or using language in a job.

Long's (1996) 'Interactive Hypothesis' and Swain's (2000) 'Pushed Output' theory, both widely embraced by educators, stress the importance of developing learners' communicative competence and promoting the active use of a second language (L2). However, research of L2 classrooms suggests that learners, particularly those from the Asian region, are unwilling to participate orally (Peng, 2012; Jackson, 2002). Researchers and educators have made considerable efforts to explore why so many learners are unwilling to speak out. A key part of these efforts has been to try to understand and even to predict learners' communicative behaviour by identifying the factors involved. However, most studies have largely neglected the dynamic nature of WTC by treating it as a static trait. Little is known about how learners' WTC fluctuates in different situations and what causes these variations. Most previous studies have focused on learners at university (Jackson, 2002; Kang, 2005; Peng, 2012), but little is known about beginner L2 learners' WTC. Nevertheless, Zhong (2013) found that the learners' WTC and oral communication varied in different situations in L2 classrooms, suggesting that WTC is context-dependent and situational. Interestingly, participants were found to be more involved in communicating with each other during collaborative learning situations. 
Zhong (2013) investigated five low-proficiency L2 learners' situational WTC in a New Zealand English as a Second Language (ESL) classroom. Drawing on Ajzen's (1991, 2005) Theory of Planned Behaviour (TPB), Zhong explored factors affecting student's WTC in different situations in L2 classrooms. Zhong's (2013) research results are not generalized, so this study draws upon that research design to further develop and investigates four hundred and sixteen L2 learners' situational WTC in English language classrooms located in Thailand. This study also draws upon Ajzen's $(1991,2005)$ TPB, by exploring factors that affect students' WTC in collaborative situations in L2 classrooms. The significance of this study is that there is very little research on attitudes and behaviour about WTC in English generally, but in particular in relation to Thai students, so this paper will help fill both gaps.

Current research validates the view that perceived communication apprehension (PCA) has the potential to predict English as a Foreign Language (EFL) WTC (Öz, Demirezen, \& Pourfeiz, 2015). Thus, this study explores the critical factors that affect undergraduate students' Willingness to Communicate English from the perspective of Perceived Communication Apprehension (PCA), Attitude Toward Willingness to Communicate ( AWTC), Subjective Norms (SN), Perceived Behavioural Control (PBC), and Willingness to Communicate (WTC). This research is useful in that it will help English lecturers improve their undergraduate students' English oral communication skill following the significant factors identified in the results of this study.

\section{Literature Review}

\section{Willingness to Communicate English}

The concept of WTC was originally developed by researchers studying first language (L1) communication, but was later extended as a significant issue in the learning a second or foreign language (Baghaei, 2012; Lee and Ng, 2009; Maftoon and Ziafar, 2013; Oz, 2014; Pattapong, 2010; Suksawas, 2011). WTC can be defined as the tendency to initiate communication and a personality trait that is unchanging over time or in different situations (McCroskey and Baer, 1985; McCroskey and Richmond, 1991). Studies in Second Language Acquisition (SLA) describe WTC as predictable from two variables: learners' Perceived Communication Competence and Communication Anxiety (Maclntyre, Clément, Baker, \& Conrod, 1998; Yashima, 2002, 2009). Thus, high levels of Perceived Competence when mixed with low levels of anxiety leads to greater WTC which, in turn, generates more frequent communication in L2 or EFL. Other factors found to correlate with, or effect WTC, are motivation (Hashimoto, 2002; Yashima, 2002), gender, age (Maclntyre, Baker, Clément, \& Donovan, 2002), attitudes toward the international community (Yashima, 2002; Yashima, Zenuk- Nishide, \& Shimizu, 2004) and personality (Maclntyre \& Charos, 1996).

Maclntyre, Clément, Baker and Conrod, (2001) examined the dynamic nature of WTC and found that when outside the classroom it was social support from friends that influenced WTC. Clément, Baker and MacIntyre, (2003) discuss how the frequency and 
quality of exposure to a second language has an effect on WTC through the mediation of L2 confidence. Many original studies relied on quantitative data, but more recent studies used qualitative methods to explore the situational nature of WTC. Kang (2005) used class observations, interviews and stimulated recall to collect qualitative data on four Korean L2 learners. Kang found that that excitement, responsibility, and security all interact with the variables of topic, interlocutors, and conversational context to determine learners' situational WTC. The work of Cao and Philp (2006) found that a group's cultural background could also affect WTC. Cao writing in 2011 found that individual, linguistic and environmental dimensions had joint effects on the situational WTC in L2 classrooms. Peng (2012) used an ecological perspective to identify six factors the underlie classroom WTC; learner beliefs, motivation, cognitive factors, linguistic factors, affective factors, and the classroom environment. From these studies the situational nature of WTC has become clearer however, more research could improve the understanding of the conditions and factors for changes to learners' WTC.

\section{Perceived Communication Apprehension (PCA)}

Communication apprehension (CA) is connected to the feeling of anxiety an individual has when communicating. Barraclough, Christophel and McCroskey (1988, p. 188) define CA as "an individual's level of fear or anxiety associated with real or anticipated communication with another person or persons". McCroskey (1997) adds to this by describing CA as having trait-like characteristics. Other research on CA has revealed that people who have high levels of fear or anxiety about communicating tend to avoid or withdraw from it altogether (Dörnyei, 2005; Maclntyre \& Charos, 1996). CA is negatively correlated with language achievement and WTC (McCroskey \& McCroskey, 2002). Interestingly, current research suggests that Perceived Communication Apprehension (PCA) might be able to predict EFL WTC (Öz et al., 2015).

$\mathbf{H}_{1}$. Perceived communication apprehension directly affects willingness to communicate in English.

In 2013 Zhong used the Theory of Planned Behaviour (TPB) in a qualitative attitudebehaviour to study the WTC of a small group of students. Zhong found that whilst TPB might provide a starting point for attitude-behaviour research, it requires additional variables to improve the sufficiency of the respective models. Ajzen (1991) also states that TPB allows for the use of additional variables to strengthen the ability to explain certain behaviours. Hence, this study will build upon Zhong's work by further investigating the relationship between PCA and TPB.

$\mathbf{H}_{2}$. Perceived communication apprehension directly affects attitude toward behaviour.

$\mathbf{H}_{3}$. Perceived communication apprehension directly affects subjective norms.

H4. Perceived communication apprehension directly affects perceived behavioural control. 
Attitude toward Behaviour (ATB), Subjective Norms (SN), Perceived Behavioural Control (PBC)

This study has utilised TPB to investigate WTC, but with additional variables. The whole set of variables, including those of TPB, are as follows:

Attitudes towards behaviour $(A B)$ refers to the behaviour beliefs of an individual that influence their behaviour and their evaluation of that behaviour (Fishbein \& Ajzen, 1975). The belief component includes a person's knowledge and perceptions about certain behaviours. Such attitudes are an important consideration as they have been shown in previous studies to influence the motivation of learners' communication behaviour (McCroskey \& Richmond, 1987; Zhong, 2013).

Subjective Norms $(S N)$ are normative beliefs, which is a subjective norm or social pressure. SN relates to the perceived expectations of the important people close to a person and how motivated they are to comply with such expectations (Fishbein \& Ajzen, 1975). Normative beliefs suggest that pressure from peers, family members, neighbourhood, teachers, school, community and society have a positive effect on communication behaviour. Many studies confirm the correlation between normative beliefs and WTC in English (Hashimoto, 2002; Yashima, 2002; Yashima et al., 2004; Zarrinabadi, 2014; Zhong, 2013).

Perceived behavioural control ( $P B C)$ relates to control beliefs. According to Bandura (1998) control beliefs are an individual's sense of self-efficacy. Ajzen's 2005 research found that an individual's control beliefs influence PBC which directly and indirectly affects behaviour through behavioural intention. McCroskey and Richmond (1987) discuss how an individual's perception of their communication competence has an impact on WTC. Barraclough et al. (1988, p. 188) explain that "it is what a person thinks he/she can do, not what he/she actually could do, which impacts the individual's behavioural choices". Therefore, an individual's unwillingness to communicate may be attributed to a lack of linguistic self-confidence and also communicative competence. Current research (Ghonsooly, Khajavy, \& Asadpour, 2012; Hashimoto, 2002; Öz et al., 2015; Zhong, 2013) supports the concept that perceived communicative competence has the potential to predict WTC.

H5. Attitude toward Willingness to Communicate directly affects Willingness to Communicate in English.

$\mathbf{H}_{6}$. Subjective Norms directly affect the Willingness to Communicate English.

H7. Perceived Behavioural Control directly affects the Willingness to Communicate English 
Figure 1: Conceptual framework

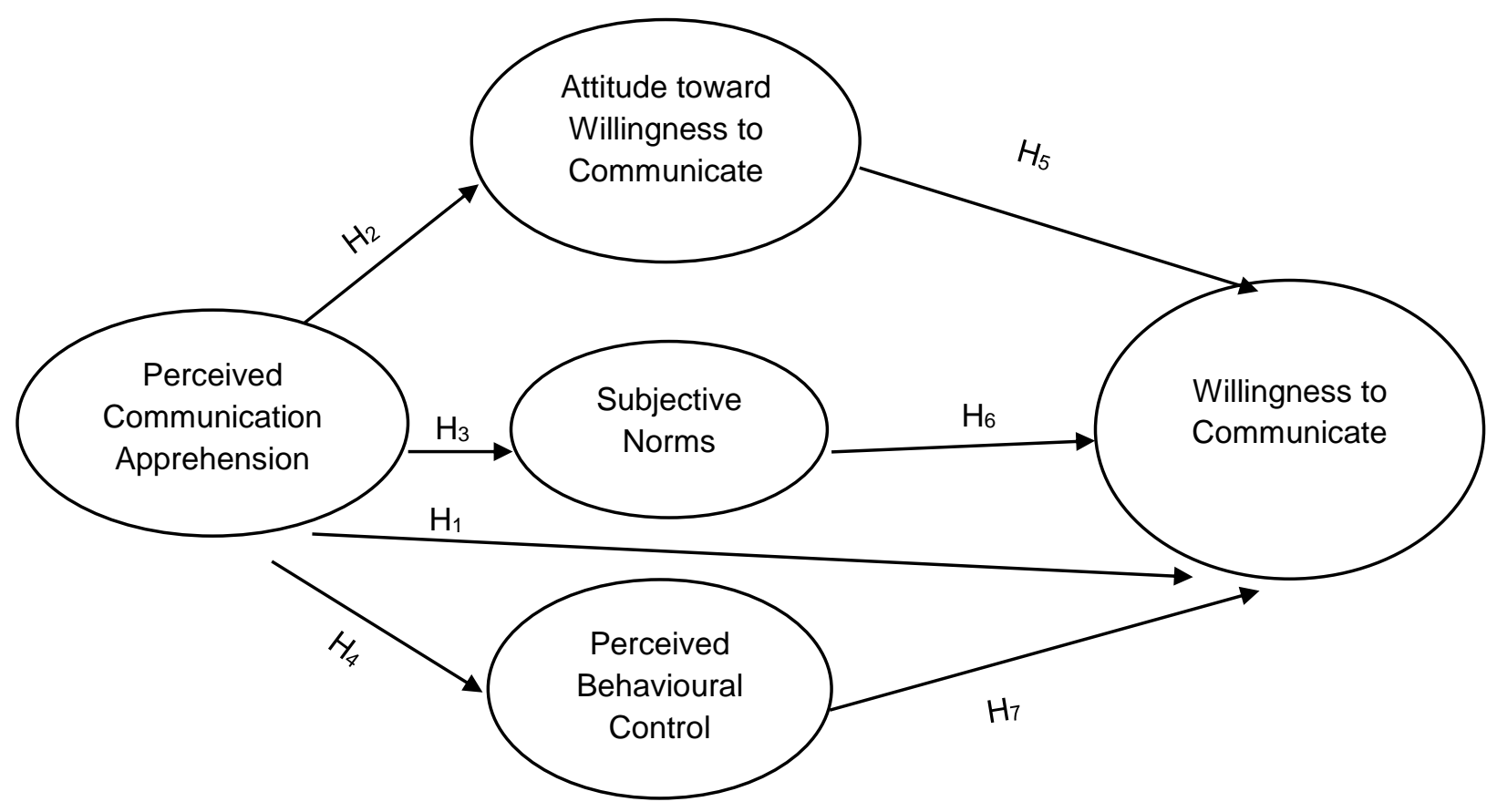

\section{Research Methodology}

\section{Sampling method and data collection}

A pilot test was conducted on a convenience sample of 30 undergraduate students to clarify the wording and improve the actual participant's understanding of the questions. Multiple stage stratified random sampling was used to select the 450 participants to complete the final version of the questionnaire. The questionnaires were distributed as hard copies as this method achieves a relatively high response rate when compared to online questionnaires (Szolnoki \& Hoffmann, 2013). For multivariable studies, Hair, Black, Babin and Anderson (2010, pp. 102) state that the proportion between samples and observed variables should be at least 5: 1 . There were 54 observed variables for this study and as 416 validated questionnaires were used for data analysis the proportions recommended by Hair et al. were achieved.

\section{Measurements}

The survey instrument developed for this research consists of three parts. The first part of the questionnaire contains questions about demographic variables, such as gender, study year, and a self-evaluation of English ability. The second part utilises adapted items from the work of Baghaei (2012) that measured perceived behavioural control (PBC). There was 1 latent variable and 12 questions in part two which were measured using a 10-point scale ranging from 0 to 10 . For part 3 , there were 4 latent variables and 42 questions, all the items used in this study were measured using 5-point Likert-type 
scales ranging from strongly disagree $=1$ to strongly agree $=5$. The questions for part 3 were developed by reference to the works of the following researchers; 9 WTC items were adapted from Baghaei, (2012), 9 PCA items from Maclntyre, Baker, Clément, \& Donovan, (1998), Maclntyre \& Clément, (1996) and Yashima, (2002), 15 AWTC items and 9 SN items to measure from Gardner, (1988) and Gardner \& Lysynchuk, (1990).

\section{Data analysis}

The statistical package for social sciences (SPSS) was used for the descriptive and inferential analyses to provide respondents' profiles and the Cronbach's Alpha reliability scores. The data from the pre-test was used to measure the reliability of research instruments. The Cronbach's alpha score for the latent variables was 0.961 which exceeded the benchmark of 0.7 (Nunnally and Bernstein, 1994), thereby suggesting a good level of internal consistency of the factor analysis (Hair, Anderson, Tatham, \& Black, 2002). A confirmatory factor analysis (CFA) was performed to empirically evaluate the construct validity of the developed components model. In part 3 , there were 4 latent variables from 42 questions (observed variables) these were reduced to 32 questions for the construct validity. After CFA, the proposed hypotheses were tested utilizing a structural equation modelling (SEM) approach. The Mplus 6.12 computer program was used to test the proposed hypotheses as shown in Table 1.

\section{Results}

Table 1: Hypotheses test from $\mathrm{H}_{1}-\mathrm{H}_{7}$

\begin{tabular}{clcccc}
\hline \multirow{2}{*}{ Hypotheses } & $\begin{array}{c}\text { Relationship between latent } \\
\text { variables }\end{array}$ & \multicolumn{3}{c}{ Factor } & \multirow{2}{*}{ Results } \\
\cline { 3 - 5 } & & $\boldsymbol{\beta}$ & $\boldsymbol{S E}$ & $\boldsymbol{t}$ & \\
\hline $\mathrm{H}_{1}$ & $\mathrm{PCA} \rightarrow$ WTC & -0.024 & 0.083 & -0.285 & Not supported \\
$\mathrm{H}_{2}$ & $\mathrm{PCA} \rightarrow \mathrm{AB}$ & 0.211 & 0.080 & $2.627^{*}$ & Supported \\
$\mathrm{H}_{3}$ & $\mathrm{PCA} \rightarrow \mathrm{SN}$ & -0.061 & 0.086 & -0.710 & Not supported \\
$\mathrm{H}_{4}$ & $\mathrm{PCA} \rightarrow$ PBC & 0.533 & 0.058 & $9.251^{* *}$ & Supported \\
$\mathrm{H}_{5}$ & $\mathrm{AB} \rightarrow$ WTC & 0.330 & 0.080 & $4.104^{*}$ & Supported \\
$\mathrm{H}_{6}$ & $\mathrm{SN} \rightarrow$ WTC & 0.272 & 0.080 & $3.373^{*}$ & Supported \\
$\mathrm{H}_{7}$ & $\mathrm{PBC} \rightarrow$ WTC & 0.361 & 0.089 & $4.071^{*}$ & Supported \\
\hline
\end{tabular}

${ }^{*} p \leq .05,{ }^{* *} p \leq .01$ 
Table 2: Demographics of Respondents

\begin{tabular}{llcc}
\hline Categories & Items & $\begin{array}{c}\text { Number of } \\
\text { responses }\end{array}$ & $\begin{array}{c}\text { Percentage of } \\
\text { responses (\%) }\end{array}$ \\
\hline Gender & Male & 191 & 45.9 \\
\hline Year of study & Female & 225 & 54.1 \\
\hline & $1^{\text {st }}$ & 88 & 21.2 \\
& $2^{\text {nd }}$ & 167 & 40.1 \\
\hline & $3^{\text {rd }}$ & 145 & 34.9 \\
\hline English language & $4^{\text {th }}$ & 16 & 3.8 \\
proficiency & Very good & 10 & 2.4 \\
& Good & 45 & 10.8 \\
& Fairly good & 51 & 12.3 \\
& Average & 188 & 45.2 \\
& Poor & 122 & 29.3 \\
\hline
\end{tabular}

Table 3: Factor loadings among observed and latent variables

\begin{tabular}{|c|c|c|c|c|c|}
\hline \multirow{2}{*}{ Items } & \multirow{2}{*}{ Descriptive } & \multicolumn{3}{|c|}{ Factor } & \multirow[b]{2}{*}{$R^{2}$} \\
\hline & & $\beta$ & SE & $t$ & \\
\hline \multicolumn{6}{|c|}{ Observed Variable } \\
\hline PCA10 & $\begin{array}{l}\text { I am tense and nervous while participating in } \\
\text { group discussions in English. }\end{array}$ & 0.683 & 0.045 & 15.131 & 0.466 \\
\hline PCA11 & $\begin{array}{l}\text { Engaging in a group discussion in English with } \\
\text { new people makes me tense and nervous. }\end{array}$ & 0.614 & 0.051 & 12.090 & 0.377 \\
\hline PCA13 & $\begin{array}{l}\text { While participating in a conversation in English } \\
\text { with a new acquaintance, I feel very nervous. }\end{array}$ & 0.683 & 0.044 & 15.414 & 0.466 \\
\hline PCA14 & $\begin{array}{l}\text { Ordinarily, I am very tense and nervous in } \\
\text { conversations in English. }\end{array}$ & 0.800 & 0.036 & 22.410 & 0.639 \\
\hline PCA16 & $\begin{array}{l}\text { Certain parts of my body feel very tense and rigid } \\
\text { while giving a presentation in English. }\end{array}$ & 0.633 & 0.048 & 13.096 & 0.400 \\
\hline PCA18 & $\begin{array}{l}\text { While giving a presentation in English I get so } \\
\text { nervous, I forget facts I really know. }\end{array}$ & 0.608 & 0.051 & 11.959 & 0.370 \\
\hline AWTC19 & I like speaking English. & 0.769 & 0.041 & 18.987 & 0.592 \\
\hline AWTC20 & Speaking English is fun. & 0.838 & 0.034 & 24.731 & 0.702 \\
\hline AWTC21 & $\begin{array}{l}\text { Being able to speak English often makes me } \\
\text { happy. }\end{array}$ & 0.763 & 0.039 & 19.377 & 0.581 \\
\hline AWTC22 & $\begin{array}{l}\text { Being able to speak English gives me a feeling of } \\
\text { success. }\end{array}$ & 0.552 & 0.055 & 10.060 & 0.305 \\
\hline AWTC25 & $\begin{array}{l}\text { I speak English because I want to communicate } \\
\text { with foreigners. }\end{array}$ & 0.380 & 0.066 & 5.763 & 0.145 \\
\hline AWTC26 & $\begin{array}{l}\text { Speaking English is important to me because I } \\
\text { want to make friends with foreigners. }\end{array}$ & 0.462 & 0.061 & 7.594 & 0.213 \\
\hline AWTC27 & $\begin{array}{l}\text { Speaking English is important to me because I } \\
\text { might study overseas. }\end{array}$ & 0.499 & 0.058 & 8.556 & 0.249 \\
\hline AWTC28 & $\begin{array}{l}\text { Speaking English is important to me because I } \\
\text { might need it later for my job. }\end{array}$ & 0.443 & 0.064 & 6.919 & 0.196 \\
\hline SN34 & $\begin{array}{l}\text { My parents think I need to speak English to be } \\
\text { well-educated. }\end{array}$ & 0.468 & 0.063 & 7.410 & 0.219 \\
\hline SN36 & $\begin{array}{l}\text { My parents encourage me to practice my English } \\
\text { speaking as much as possible. }\end{array}$ & 0.695 & 0.047 & 14.872 & 0.483 \\
\hline
\end{tabular}




\begin{tabular}{|c|c|c|c|c|c|}
\hline \multirow{2}{*}{ Items } & \multirow{2}{*}{ Details } & \multicolumn{3}{|l|}{ Factor } & \multirow[b]{2}{*}{$R^{2}$} \\
\hline & & $b$ & SE & $t$ & \\
\hline SN37 & $\begin{array}{l}\text { My friends think that speaking English is } \\
\text { important. }\end{array}$ & 0.527 & 0.059 & 8.966 & 0.277 \\
\hline SN38 & $\begin{array}{l}\text { For my friends, speaking English is a sign of being } \\
\text { well-educated. }\end{array}$ & 0.434 & 0.065 & 6.695 & 0.188 \\
\hline SN40 & My friends encourage me to speak English. & 0.720 & 0.045 & 15.943 & 0.518 \\
\hline SN42 & $\begin{array}{l}\text { My friends have a positive impact on encouraging } \\
\text { me to speak English. }\end{array}$ & 0.732 & 0.043 & 16.938 & 0.535 \\
\hline PBC1 & Present a talk to a group of strangers. & 0.896 & 0.017 & 52.106 & 0.803 \\
\hline PBC2 & Talk with an acquaintance. & 0.856 & 0.021 & 40.363 & 0.733 \\
\hline PBC3 & Talk in a large meeting of friends. & 0.816 & 0.024 & 34.135 & 0.666 \\
\hline PBC6 & Talk in a large meeting of acquaintances. & 0.861 & 0.020 & 43.491 & 0.741 \\
\hline PBC7 & Talk with a stranger. & 0.837 & 0.022 & 37.750 & 0.700 \\
\hline PBC8 & Present a talk to a group of friends. & 0.909 & 0.017 & 53.585 & 0.827 \\
\hline PBC9 & Talk in a small group of acquaintances. & 0.830 & 0.023 & 36.158 & 0.689 \\
\hline WTC5 & $\begin{array}{l}\text { If I was introduced to a native English speaker, I } \\
\text { would be happy to use my ability at English to } \\
\text { communicate with them. }\end{array}$ & 0.581 & 0.053 & 10.906 & 0.338 \\
\hline WTC6 & $\begin{array}{l}\text { I am willing to ask questions, in English, in front of } \\
\text { my classmates. }\end{array}$ & 0.650 & 0.047 & 13.755 & 0.423 \\
\hline WTC7 & $\begin{array}{l}\text { I am willing to express my opinions, in English, in } \\
\text { front of my classmates. }\end{array}$ & 0.678 & 0.044 & 15.420 & 0.460 \\
\hline WTC8 & $\begin{array}{l}\text { I am willing to talk, in English, with my teachers } \\
\text { when out of the classroom. }\end{array}$ & 0.674 & 0.052 & 13.035 & 0.454 \\
\hline \multicolumn{6}{|c|}{ Latent Variable } \\
\hline PCA & Perceived communication apprehension & - & - & - & - \\
\hline AWTC & Attitude toward willingness to communicate & - & - & - & 0.044 \\
\hline SN & Subjective norms & - & - & - & 0.004 \\
\hline PBC & Perceived behavioural control & - & - & - & 0.284 \\
\hline WTC & Willingness to communicate & - & - & - & 0.572 \\
\hline \multicolumn{6}{|c|}{$\begin{array}{l}\chi^{2}=446.558, \mathrm{df}=410, p \text {-value }=0.103, \mathrm{CFI}=0.990, \mathrm{TLI}=0.988, \mathrm{RMSEA}=0.021, \mathrm{SRMS}= \\
0.061\end{array}$} \\
\hline
\end{tabular}

The measurement model with 32 indicators and 5 constructs (Figure 2 ) resulted in a very good overall model fit $\chi^{2}=446.558, \mathrm{df}=410, p$-value $=0.103, \mathrm{CFI}=0.990, \mathrm{TLI}=0.988, \mathrm{RMSEA}=$ $0.021, \mathrm{SRMS}=0.061$. Based on the fit statistics, this study concluded that the measurement model was an adequate measurement instrument for estimated concepts of the structural model. Of the hypotheses on the relationships among the constructs tested in the final model 5 hypotheses $\left(\mathrm{H}_{2}, \mathrm{H}_{4}-\mathrm{H}_{7}\right)$ were supported and 2 hypotheses $\left(\mathrm{H}_{1}, \mathrm{H}_{3}\right)$ not supported. 
Figure 2: Structural Equation Model Test

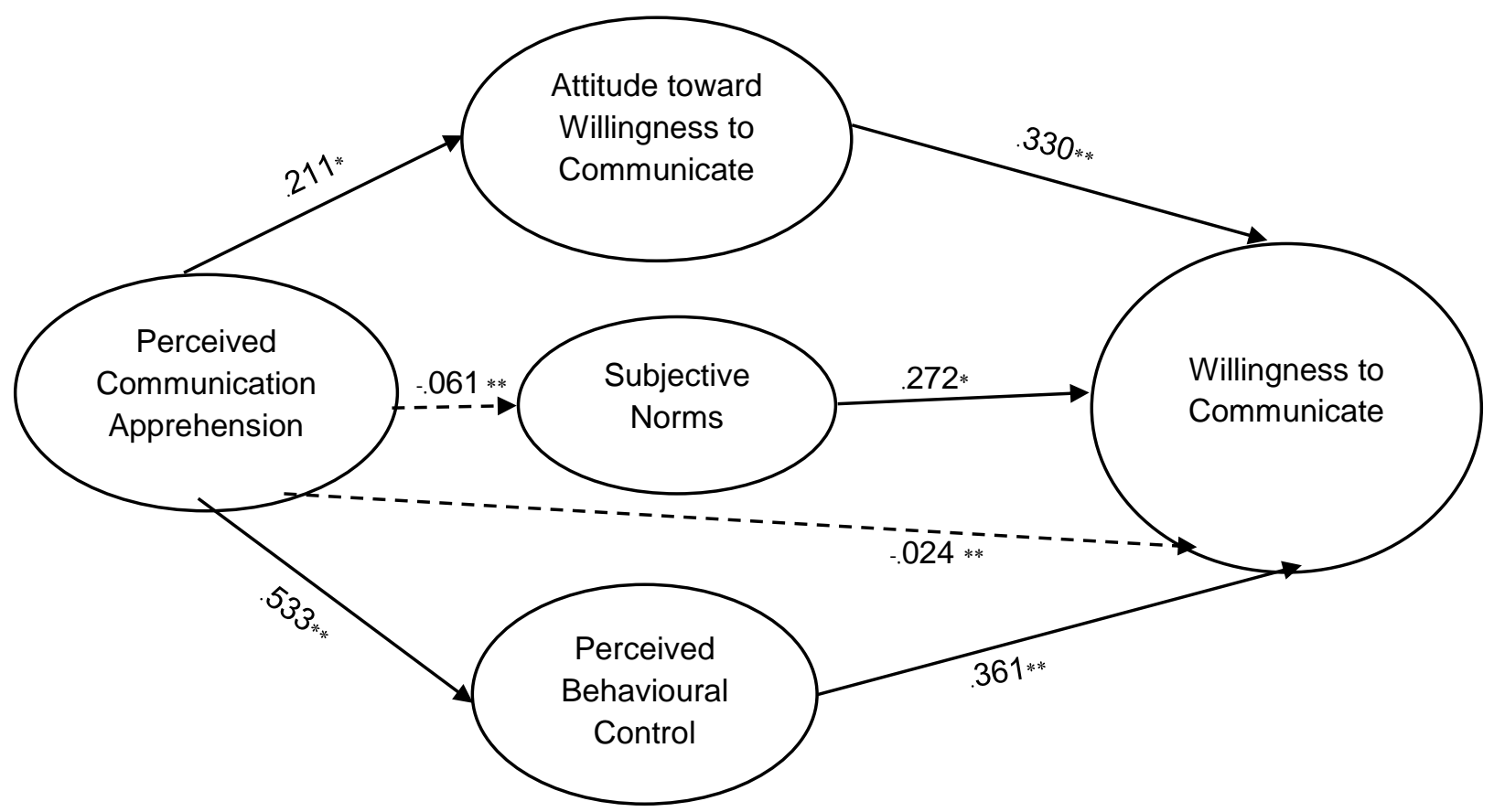

\section{Discussion}

As Zhong (2013) adopted the Theory of Planned Behaviour (TPB) in a qualitative attitude-behaviour study on the Willingness to Communicate English (WTC), this study also utilised TPB to investigate WTC. The results indicate that the relationship among the TPB and WTC constructs are supported $\left(\mathrm{H}_{5}-\mathrm{H}_{7}\right)$. The findings also show that Perceived Behavioural Control (PBC) affects students' Willingness to Communicate in English the most $(\beta=0.361, t=4.071)$. The second most significant result was, students' Attitude Towards Willingness to Communicate in English (AWTC) and how it affects their Willingness to Communicate in English $(\beta=0.330, t=4.104)$. The third was Subjective Norms which affects the Willingness to Communicate in English as a result of student' perspectives $(\beta=0.272, t=3.373)$.

The relationship between PBC and WTC was significant $\left(\mathrm{H}_{7}\right)$ in this research, thereby supporting previous research (Ghonsooly et al., 2012; Hashimoto, 2002; McCroskey \& Richmond, 1987; Öz et al. , 2015; Zhong, 2013). The highest factor loading value was in the PBC' indicators, 'to present a talk to a group of friends' (PBC8). Students evaluated themselves as having a low sense of self-efficacy to speak English to a group of their friends. Thus, supporting the work of Christophel and McCroskey (1988), who found an individual's unwillingness to communicate could be attributed to a lack of linguistic self-confidence and also communicative competence.

The relationship between AWTC and WTC was supported $\left(\mathrm{H}_{5}\right)$ which correlated previous study's findings that students' attitude is an important factor in motivating learners' communication behaviour (McCroskey \& Richmond, 1987; Zhong, 2013). In 
AWTC indicators, 'speaking English is fun' ( AWTC20), 'I like speaking English' (AWTC19), 'Being able to speak English often makes me happy' (AWTC21) had the highest factor loadings. This supports the previous research of Fishbein and Ajzen (1975), who found attitude toward behaviour is as function of an individual's beliefs towards behaviour and a subjective evaluation of that behaviour. Therefore, when students evaluate that speaking English is fun and it makes them happy then they might have a willingness to speak English.

The relationship between SN and WTC was supported $\left(\mathrm{H}_{6}\right)$ which correlates with previous studies that found students' attitude is an important factor in motivating learners' communication behaviour (McCroskey \& Richmond, 1987; Zhong, 2013). In AWTC' indicators, 'speaking English is fun' (AWTC20), 'I like speaking English' (AWTC19), 'Being able to speak English often makes me happy' (AWTC21) were all associated with previous studies (Hashimoto, 2002; Yashima, 2002; Yashima et al., 2004; Zarrinabadi, 2014; Zhong, 2013). In SN indicators, 'my friends have a positive impact on encouraging me to speak English' ( $\mathrm{SN} 42$ ) and 'my friends encourage me to speak English' (SN40) indicated that students' friends influence their willingness to speak English the most.

The relationship between PCA and WTC was not supported for two hypotheses $\left(\mathrm{H}_{1}\right.$ and $\mathrm{H}_{3}$ ), but PCA affected Attitude toward Willingness to Communicate English (AWTC) $\left(\mathrm{H}_{2}\right)$, and it also affected Perceived Behavioural Control (PBC) $\left(\mathrm{H}_{4}\right)$. These findings constituted the new knowledge that PCA affected WTC in an indirect way via AWTC and PBC for undergraduate students. The three PCA' indicators, 'I am very tense and nervous in conversations in English' (PCA14: Mean $=2.43$ ), 'I am tense and nervous while participating in group discussions in English' (PCA), and 'while participating in a conversation in English with a new acquaintance, I feel very nervous' (PCA13: Mean = 2. 26) indicated that students were tense and nervous to speak English with new acquaintances and in group discussions which was associated with PBC that students were most concerned when speaking to a group of friends (PBC9: Mean $=2.34)$, and a group of strangers (PBC1: Mean = 2.44). Moreover, 'speaking English is fun' (AWTC20: Mean $=3.71)$, and 'it makes me happy' (AWTC21: Mean $=3.74)$ were indicators that considerably concerned students.

These relationship among PCA, AWTC and PBC indicate that students would have the willingness to express their opinions, in English, in front of their classmates (WTC7: Mean $=3.24$, which concerned students the most), a group of friends, a group of strangers or acquaintance if they feel that speaking English is fun and it makes them happy without feeling any tension. Conversely, when students are tense and nervous to speak English with their friends, strangers and new acquaintance the mean value of PCA and PBC was lower than the moderated level. 


\section{Conclusion}

Students' PCA can influence WTC indirectly via AWTC and PBC. WTC was not affected from PCA indirectly via SN. The highest total effect on WTC was PBC. To determine which latent variable indicators students were highly concerned about, this research concluded that students feet tense and nervous to speak English with their friends, strangers, and new acquaintance.

Why are undergraduate students tense and nervous to be willing to speak English with friends, new acquaintance, and strangers? This question is posed from the findings that relate to PCA, AWTC, PBC and WTC. The answer could be suggested by factors that have been found to be correlated with, or effect, WTC. These include motivation (Hashimoto, 2002; Yashima, 2002), gender, age (Maclntyre et al., 2002), attitudes towards the international community (Yashima, 2002; Yashima et al., 2004) and personality (Maclntyre \& Charos, 1996). Moreover, Cao (2011) reported that three dimensions (individual, linguistic and environmental), had joint effects on the situational WTC in L2 classrooms. Further studies could add additional variables such as personality, attitudes toward the international community and the self-motivation level of students in order to compare in the causal relationship model of undergraduate students' Willingness to Communicate in English. Such further research could advance the understanding of the conditions and factors to make changes in learners' WTC.

\section{References}

Ajzen, I. (1991). The theory of planned behaviour. Organizational Behaviour and human Decision Processes, 50, 179-211.

Ajzen, I. (2005). Attitudes, Personality and Behavior (2nd ed.). Maidenhead: Open University Press.

Bandura, A. (1998). Health promotion from the perspective of social cognitive theory. Psychology and Health, 13, 623-649.

Baghaei, P. (2012). The Relationship between willingness to communicate and success in learning English as a foreign language. MJAL, 4(2), Summer 2012.

Barraclough, R. A., Christophel, D. M., \& McCroskey, J. C. (1988). Willingness to communicate: A cross-cultural investigation. Communication Research Reports, 5(2), 187-192.

Clément, R., Baker, S., \& Maclntyre, P. (2003). Willingness to communicate in a second language: the effects of context, norm, and vitality. Journal of Language and Social Psychology, 22(2), 190-209.

Cao, Y. (2011). Investigating situational willingness to communicate within second language classrooms from an ecological perspective. System, 39, 468-479.

Dörnyei, Z. (2005). The Psychology of the Language Learner: Individual Differences in Second Language Acquisition. Mahwah, NJ: Lawrence Erlbaum. 
EF, (Education First), (2012), English Proficiency Index, (EPI), Retrieved from; www.ef.co.uk

Fishbein, M., \& Ajzen, I. (1975). Belief, Attitude, Intention, and Behaviour: An Introduction to Theory and Research. Reading, MA: Addison-Wesley.

Gardner, R. C. (1988). The socio-educational model of second-language learning: assumptions, findings, and issues. Language Learning, 38, 101-126.

Gardner, R. C., \& Lysynchuk, L. M. (1990). The role of aptitude, attitudes, motivation and language use on second-language acquisition and retention. Canadian Journal of Behavioural Science, 22, 254270.

Ghonsooly, B., Khajavy, G. H., \& Asadpour, S. F. (2012). Willingness to communicate in English among Iranian non-English major university students. Journal of Language and Social Psychology, 31(2), 197-211.

Hair, J. F. Jr., Anderson, R. E., Tatham, R. L., Black, W. C. (2002). Multivariate Data Analysis (6th ed.). Englewood Cliffs, NJ: Prentice-Hall.

Hair, J., F., Black, W., C., Babin, B., J., Anderson, R., E. (2010). Multivariate Data Analysis: A Global perspective (Global ed.). New Jersey: Pearson.

Hashimoto, Y. (2002). Motivation and willingness to communicate as predictors of reported L2 use: the Japanese ESL context. Second Language Studies, 20(2), 29-70.

Jackson, J. (2002). Reticence in second language case discussions: anxiety and aspirations. System, $30,65-84$.

Kang, S. (2005). Dynamic emergence of situational willingness to communicate in a second language. System, 33, 277-292.

Lee, W., \& Ng, S. (2009). Reducing student reticence through teacher interaction strategy. ELT Journal, 64(7), 302-313.

Long, M. (1996). The role of the linguistic environment in second language acquisition. In: Rithcie, W., Bhatia, T. (Eds.), Handbook of Second Language Acquisition. San Diego: Academic Press.

Maftoon, P., \& Ziafar, M. (2013). Effective Factors in Interactions within Japanese EFL Classrooms. The Clearing House, 86, 74-79.

Maclntyre, P. D. (2007). Willingness to communicate in the second language: Understanding the decision to speak as a volitional process. The Modern Language journal, 91(5), 564-576.

MacIntyre, P. D., \& Charos, C. (1996). Personality, attitudes, and affect as predictors of second language communication. Journal of Language and Social Psychology, 15(1), 3-26.

Maclntyre, P. D. \& Clément, R. (1996). A Model of willingness to communicate in a second language: The concept, its antecedents and implications. Paper presented at the World Congress of Applied Linguistics (AILA). Jyväskylä, Finland, August, 4-9. 
Macintyre, P., Clément, R., Baker, S., \& Conrod, S. (2001). Willingness to communicate, social support and language learning orientations of immersion students. Studies in Second Language Acquisition, 23, 369-388.

Maclntyre, P., Dornyei, Z., Clément, R., \& Noels, K. (1998). Conventionalizing willingness to communicate in a L2: a situational model of L2 confidence and affiliation. Modern Language Journal, 82(3), 545-562.

Macintyre, P., Baker, S., Clément, R., \& Donovan, L. A. (2002). Sex and age effects on willingness to communicate, anxiety, perceived competence, and L2 motivation among junior high school French immersion students. Language Learning, 52, 537-564.

McCroskey, J. C. (1997). Willingness to communicate, communication apprehension, and self-perceived communication competence: Conceptualization and perspectives. In J. Daly, \& J. C. McCroskey (Eds.), Avoiding communication: shyness, reticence, and communication apprehension (pp. 75108). Cresskill, NJ: Hampton Press.

McCroskey, J. C., \& Baer, J. E. (1985). Willingness to communicate: The construct and its measurement. Paper presented at the Annual Convention of the Speech Communication Association, Denver, Colorado.

McCroskey, J. C., \& Richmod, V. P. (1987). Willingness to communicate and interpersonal communication. In J. C. McCroskey, \& J. A. Daly (Eds.), Personality and interpersonal communication (pp. 129-156). Beverly Hills, CA: Sage.

McCroskey, J. C., \& Richmond, V. P. (1991). Willingness to communicate: a cognitive view. In: BoothButterfield, M. (Ed.), Communication, Cognition and Anxiety. Sage, Newbury Park, CA, pp. 1937.

McCroskey, L. L., \& McCroskey, J. C. (2002). Willingness to communicate and communication apprehension. In J. L. Chesebro, \& J. C. McCroskey (Eds.), Communication for teachers. Needham Heights, MA: Allyn \& Bacon.

Nunnally, J. C., \& Bernstein, I. H. (1994). Psychometric Theory (3rd ed.). New York: McGraw-Hill.Oz, H. (2014). Big five personality traits and willingness to communicate among foreign language learners in Turkey. Social behavior and personality, 42(9), 1473-1482.

Öz, H., Demirezen, M., \& Pourfeiz, J. (2015). Willingness to communicate of EFL learners in Turkish context. Learning and Individual Differences, 37, 269-275.

Pattapong, K, (2010). Willingness to communicate in a second language:A qualitative study of issues affecting Thai EFL learners from students' and teachers' points of view. Doctor of philosophy thesis requirements for the University of Sydney, 2010. 
Peng, J. (2012). Towards an ecological understanding of willingness to communicate in EFL classrooms in China. System, 40, 203-213.

Szolnoki, G., \& Hoffmann, D. (2013). Online, face-to-face and telephone surveys-Comparing different sampling methods in wine consumer research. Wine Economics and Policy, 2(2), 57-66.

Suksawas, W. (2011). A sociocultural study of EFL learners' willingness to communicate. Doctor of education thesis, Faculty of education, University of Wollongong, Retrieved from; http://ro.uow.edu.au/these/3427

Swain, M. (2000). The Output Hypothesis and Beyond: Mediating Acquisition Through Collaborative Dialogue. In: Lantolf, J. (Ed.), Sociocultural Theory and Second Language Learning. Oxford: Oxford University Press.

Yashima, T. (2002). Willingness to communicate in a second language: the Japanese EFL context. Modern Language Journal, 86, 54-66.

Yashima, T. (2009). International posture and the ideal L2 self in the Japanese EFL context. In: Dörnyei, Z., Ushioda, E. (Eds.), Motivation, Language Identity and the L2 Self. Multilingual Matters, Bristol, pp. 144-192.

Yashima, T., Zenuk-Nishide, L., \& Shimizu, K. (2004). The influence of attitudes and effect on willingness to communicate and second language communication. Language Learning, 54, 119-152.

Zarrinabadi, N. (2014). Communicating in a second language: Investigating the effect of teacher on learners' willingness to communicate. System, 42, 288-295.

Zhong, Q. (2013). Understanding Chinese learners' willingness to communicate in a New Zealand ESL classroom: A multiple case study drawing on the theory of planned behaviour. System, 41, 740751. 